\title{
Correction
}

\section{Correction to: Lipid droplets and mitochondria are anchored during brown adipocyte differentiation}

\author{
Liujuan Cui ${ }^{1,2}$, Mirza Ahmed Hammad ${ }^{2,3}$, Shuyan Zhang ${ }^{2}$, Bin Liang ${ }^{4}$, Pingsheng Liu ${ }^{1,2,3 \bowtie}$ \\ ${ }^{1}$ School of Life Sciences, University of Science and Technology of China, Hefei 230027, China \\ ${ }^{2}$ National Laboratory of Biomacromolecules, CAS Center for Excellence in Biomacromolecules, Institute of Biophysics, \\ Chinese Academy of Sciences, Beijing 100101, China \\ ${ }^{3}$ University of Chinese Academy of Sciences, Beijing 100049, China \\ ${ }^{4}$ State Key Laboratory of Conservation and Utilization of BioResources in Yunnan, and Center for Life Sciences, School of Life \\ Sciences, Yunnan University, Kunming 650091, Yunnan, China \\ $\triangle$ Correspondence: pliu@ibp.ac.cn (P. Liu)
}

\section{CORRECTION TO: \\ PROTEIN CELL 2019, 10(12):921-926 \\ HTTPS://DOI.ORG/10.1007/S13238-019-00661-1}

The authors would like to update the supplementary information in the published original version. The updated supplementary material is provided in this correction.

\section{OPEN ACCESS}

This article is licensed under a Creative Commons Attribution 4.0 International License, which permits use, sharing, adaptation, distribution and reproduction in any medium or format, as long as you give appropriate credit to the original author(s) and the source, provide a link to the Creative Commons licence, and indicate if changes were made. The images or other third party material in this article are included in the article's Creative Commons licence, unless indicated otherwise in a credit line to the material. If material is not included in the article's Creative Commons licence and your intended use is not permitted by statutory regulation or exceeds the permitted use, you will need to obtain permission directly from the copyright holder. To view a copy of this licence, visit http:// creativecommons.org/licenses/by/4.0/.
Electronic supplementary material The online version of this article (https://doi.org/10.1007/s13238-020-00800-z) contains supplementary material, which is available to authorized users.

The original article can be found online at https://doi.org/10.1007/ s13238-019-00661. 